\title{
Evaluation of Perceptions of Secondary School Students About the Concept of "Music" by Metaphors
}

\author{
Koray Çelenk \\ Correspondence: Koray Çelenk, Fine Arts Faculty Musicology Deparment, Ataturk University, Erzurum, 25240, \\ Turkey.
}

Received: May 29, 2019

doi:10.11114/jets.v7i9.4304
Accepted: July 1, 2019

Online Published: July 9, 2019

URL: https://doi.org/10.11114/jets.v7i9.4304

\begin{abstract}
Metaphor is associated with expressions such as symbolic expression, connotation and simile. Metaphor is the use of similes to liken, compare and explain something with another. The concepts have been tried to be analyzed through metaphors in many studies. Although studies on the analysis of metaphors in different branches and branches of studies are frequently encountered, studies on analysis through metaphors in music and music education are less common than other areas of education. This study aims to analyze the opinions of secondary school students about music concept by means of metaphors, and to determine the students' perceptions regarding music and music lesson through metaphors and to give a different and effective direction to music education. The study group consisted of 1003 students attending at the 5th, 6th, 7th and 8th grades at nine secondary schools selected from Erzurum, Turkey in 2017-2018 academic year by Random Sampling method. The study was carried out by the Descriptive Research Model. In this study, Phenomenology, one of the qualitative research methods, was used and the data were processed by the Content Analysis method. The data obtained were digitized and analyzed by coding in SPSS packet program. As a result of this research, it was determined that secondary school students had a high interest and affection towards music and music lesson and their music preferences were pop music. In addition, 68 kinds of metaphors and 13 kinds of conceptual categories related to music were obtained from 1003 participants. It was found that the most frequently repeated metaphors were "Friend" and "Love", and generally the students' perceptions were positive towards the concept of music and music lesson, and the metaphors produced differed according to gender, class and music preference variables.
\end{abstract}

Keywords: music, music education, metaphor

\section{Introduction}

Mankind is surrounded by a world of voices, full of voices starting from the mother's womb. In this world of sound, music which has existed in the life of mankind since the early days of history, has emerged as a common product of both emotions and mind through sounds. It has the power to unite people or communities and maintains its existence as a natural element endowed by God in the environment in which we are born is an abstract concept.

Since music is an abstract concept, it is also natural to have direct or indirect metaphoric structures within the colourful spectrum and free expression of music. It can be seen that many metaphors are used in both the musical structures and the lyrics of the musical works. For example, conceptualization of major tones and minor tones described respectively as cheerful and brightful, sentimental and sad originates within the metaphoric structure of music. According to Zbikowski (2008), it is not surprising that the language of music is often metaphorical and related to metaphors, given the area that includes the expression of music and its language independence.

The word "Metaphor" is based on the word "metapherein", which is a combination of the words "meta" with a meaning of change and "pherein" as "carry" in Greek (Levine, 2005). Semantically speaking, it is defined as transferring, metamorphosis, using a word out of its natural meaning and the semantic shift. Latin authors used this concept as transference, transportation or analogy (Nasalski, 2004).

Metaphor has been interpreted in a similar way by many researchers in the literature. Eraslan (2011); Lakoff \& Johnson (2015); Taylor (1984); Yob (2003); Morgan (1997); Saban, Koçbeker, \& Saban (2006) and Wagenheim, Clark, \& Crispo (2009) had common views on metaphor as a powerful mental tool for effective understanding and explaining a highly abstract, complex, or theoretical phenomenon. In accordance with these common views, metaphor can be defined as a metaphorical tool that enables to have a relationship and comparison between these two concepts by assigning the 
meaning symbolized by desired concept to another concept through symbolic expression, connotation and analogy.

"It is necessary to concretize the abstract concepts in order to be able to put into words. Contextualizations are parallel to the experiences of individuals. Metaphors are an indispensable tool for individuals to make concretization" (Su, Sağlam, \& Mutlu, 2017). According to Lakoff \& Johnson (2015), individuals tend to tell the truths whether they are aware or unaware of their experiences, while using metaphors.

Forceville (2002) and Leino \& Drakenberg (1993) agree that the metaphor is composed of two parts, basically referred to as meaning or subject and tool or source. Meaning is now commonly referred to as the subject or main subject and is used to describe something. Tool or source are the terms used metaphorically for reference or attribution (Balc1, 1999). For example, "Music is like oxygen. Because, as the body needs oxygen, the soul needs music". Within this statement, "Music is like oxygen" stands for the subject and "Because, as the body needs oxygen, the soul needs music" serves as a reference.

Metaphor is used for a great many reasons and art is one of these reasons. Art partly means avoiding monotony. Art often prefers describing an event by means of indirect ways and giving more pleasure to using ordinary ways through direct description (Demirci, 2016). Metaphor is one of the most important tools of music because of its inherent nature.

Aydıner Uygun (2015) states that the studies in which metaphor is used as a data collection tool in the music literature have three types. In the first type of studies, the metaphorical narrative of the verbal-non-verbal music works is discussed. In addition to the main meaning in the works, the existing semantic meanings constitute metaphorical expressions. The second type of studies is the use of metaphor as a teaching tool in the formation and development of musical expression. In the third type of studies, metaphor functions as a basic data collection tool in determining the perceptions of music concepts.

Metaphors are generally scientific studies used as a data collection tool in educational sciences. They are created by the qualitative research paradigm and serve as a tool to reveal the perceptions of the population that provides data in the metaphor form (Kilcan, 2019).

Besides being an art and science branch, music is one of the sub-dimensions of education with its educational dimension. General Music Education, which is one of the subtitles of Music Education, is the most important element of the common and general culture within the framework of Curriculum Program, in compulsory or selective-compulsory, including the kindergarten, primary school, secondary school and high school levels in our country. The aim of this course is to provide the basic knowledge and skills about music education (Çelenk \& Özşen, 2018).

Uçan (2005) asserts that today the aim of General Music Education is to educate the masses who use music with a knowledgeable, conscious, sensible and sensitive understanding. Music educators endeavor to educate individuals for this purpose. However, despite it has been proven by a great number of studies that music has a positive impact on the life of the child, and on his/her analytical and practical thinking, language skills development and socialization and the success in other lessons, it is an undeniable fact that today, especially in secondary and high schools, music and music lessons are not given importance.

In secondary schools, music lessons have effective functions in the musical acculturation, the formation and development of music appreciation and orientation through listening music, singing, playing and producing for students. It is important to determine the perceptions of the student about music concept in performing these functions of the music lessons. In determining this perception, "metaphor" can be used as a tool to explain the concepts of thinking and vision by enabling students to express concrete concepts that are abstract. With the determination of perceptions about music, the importance of teaching-learning of the music lesson and its benefits in the student's life can be explained (Tez \& Aydıner Uygun, 2016). Şahin (2013) emphasizes that teachers have an important role to play in teaching, to make them learn, to make them feel important and to have a significant influence on the success of the course.

In line with the aforementioned views, it is thought that this study is important in terms of giving clues about teaching-learning, processing, benefits of music lesson to researchers and music teachers. In addition, it is thought that the determination of students' perceptions of music through metaphors is important for music teachers to make the students love the lesson, to make them learn, to make the lesson feel important and to increase the success in the lesson. It is thought that the determination of the importance given to music by the metaphors created will eliminate the insignificant attitude towards music lesson in our society.

In this context, metaphor is used to determine the students' perceptions about music concept and aimed to give a different and effective direction to the music education in this study.

The research questions are as follows:

1. What is the distribution of secondary school students' perceptions about music and music lesson? 
2. What are the metaphors of secondary school students in their perceptions of the concept of "Music"?

3. What are the conceptual categories of metaphors in secondary school students' perceptions of the concept of "Music?

4. Do metaphors formed by secondary school students in their perceptions of music concept differ according to gender, class and preferred music genre?

\section{Method}

\subsection{The Model of Research}

Phenomenology pattern focuses on the facts that we are aware of, but do not have in-depth and detailed understanding. The phenomena can be seen in various forms such as events, experiences, perceptions, orientations, concepts and situations in the world we live in. Data sources in the phenomenology research are individuals or groups who focus on the phenomenon of the research and who can reflect this phenomenon and the main data collection tool is the interview. Data analysis in phenomenology research is aimed at revealing experiences and meanings. In the content analysis carried out with this purpose, there is an attempt to conceptualize the data and to reveal the themes that can define the phenomenon. The results are presented with a descriptive narrative and often direct quotations are included. In addition, the findings obtained within the framework of themes and patterns are explained and interpreted (Y1ldırım \& Şimşek, 2008).

The content analysis is the categorization of verbal or written data through scanning to be classified in terms of specific variables or concepts, to be summarized, to measure certain variables and concepts and derive certain meaning from them (Fox, 1969). It allows for verbal-written data, subsequent statistical processing, and important information about a particular concept, opinion, status, feature, or variable (Tavşanc1l \& Aslan, 2001).

In the direction of these information, this study bears a qualitative feature carried out by the Descriptive Model. Within this direction, Phenomenology Pattern, which is one of the qualitative research methods, was used and the obtained data were processed by Content Analysis method.

\subsection{Study Group}

The study group consisted of 1003 students attending 5th, 6th, 7th and 8th grades in nine secondary schools selected from Erzurum, Turkey in 2017-2018 academic year by Random Sampling method. The schools and the student distributions of the study group are shown in Table 1 and Table 2.

Table 1. The distribution based on gender and class variables

\begin{tabular}{lcc}
\hline Gender & $\mathbf{f}$ & $\mathbf{\%}$ \\
\hline Male & 504 & 50.2 \\
Female & 499 & 49.8 \\
\hline Total & $\mathbf{1 0 0 3}$ & $\mathbf{1 0 0}$ \\
\hline Grade & $\mathbf{f}$ & $\mathbf{\%}$ \\
\hline $5^{\text {th }}$ Grade & 257 & 25.7 \\
$6^{\text {th }}$ Grade & 322 & 32.1 \\
$7^{\text {th }}$ Grade & 235 & 23.4 \\
$8^{\text {th }}$ Grade & 189 & 18.8 \\
\hline Total & $\mathbf{1 0 0 3}$ & $\mathbf{1 0 0}$ \\
\hline
\end{tabular}


Table 2. The distribution based on school variables

\begin{tabular}{lcc}
\hline School & f & \% \\
\hline Osman Gazi Secondary School & 197 & 19.6 \\
Kayakyolu ÇMİS Secondary School & 127 & 12.7 \\
19 Mayıs Secondary School & 105 & 10.4 \\
Ahmet Yesevi Secondary School & 105 & 10.4 \\
Atatürk Secondary School & 100 & 10.0 \\
Mehmetçik Secondary School & 100 & 10.0 \\
1071 Malazgirt Secondary School & 98 & 9.8 \\
Sabahattin Solakoğlu Secondary School & 88 & 8.8 \\
Aşık Yaşar Reyhani Secondary School & 83 & 8.3 \\
\hline Total & $\mathbf{1 0 0 3}$ & $\mathbf{1 0 0}$ \\
\hline
\end{tabular}

2.3 Collection of Data

Within the scope of the method, a literature review was performed and a related conceptual infrastructure was formed. Additionally, the metaphor form, which was prepared as a data collection tool, was applied to the participants in the study group schools by the researcher himself. The purpose of the study is to inform the participants about the fact that the metaphor to be formed is not the right or wrong. It is necessary to produce a single metaphor about the concept and the reason for the metaphor produced is to explain in the sentence that starts with "Because "and to prevent each other from making metaphors, to provide more accurate and healthy results. The data collection tool was arranged as a two-part form. In the first part, a form was formed for the students' "demographic information and their perceptions about music and music lesson. In the second part, data were obtained through a semi-structured form containing some expressions like "Music is like....Because ......" in order to reveal the perceptions of the students related to music concept. The metaphors were produced with the expression "Music is like ....." and the metaphor categories were produced with the expression "Because...".

\subsection{Statistical Analysis}

The data were analyzed and interpreted using Saban (2009) and the data were analyzed by digitizing and analyzed in IBM SPSS 22.0 package program. Process steps are as follows:

\subsubsection{Metaphor Coding and Sorting}

At this stage, the metaphor forms were numbered starting from 1, and it was examined whether metaphors were significantly expressed by the participants. The forms that include the metaphor of the concept of "Music", the forms with no justification, the forms with the justification of the "Music" concept, and the forms that have no metaphor or justification for the concept of "Music" were marked out of the analysis. The metaphors in the other forms were reviewed and the correlation between the metaphorical similarity and simulation were analyzed by content analysis.

\subsubsection{Category Development}

The metaphors produced regarding the concept "Music" by the participants in the metaphor forms were categorized according to the justification of the metaphors created by the participants. Metaphor form numbers were matched to the categories associated with this metaphor for justification and the category development process was completed.

\subsubsection{Validity and Reliability}

For the validity of the research, the metaphor and conceptual category lists created were presented to the opinion of three field experts in order to demonstrate whether metaphors represent conceptual categories. In addition, by using direct quotations from the justification of the metaphors developed by the participants, the examples related to the objective views that reflect the generality of the answers were used and the credibility of the research for the validity was tried to be put forward.

For reliability, the criticism of the experts and the categories of the researcher were compared in accordance with the opinions received from the experts, and the number of consensus and the number of difference of opinions were determined and Miles \& Huberman's (1994) [Consensus / Consensus + Disagreement] formula was used. 
Table 3. The calculation table for the reliability of the research

The Experts Opinions

Consensus

Disagreement

Total Metaphor

\section{Number of Metaphors}

64

4

68

\section{Reliability Formula}

Consensus / Consensus + Disaggrement

Reliability

It is accepted that the desired level of reliability is achieved in cases where the compliance obtained according to this formula is $90 \%$ and above. Accordingly, the reliability of the 68 metaphors obtained was calculated as .94. In other words, the metaphors obtained are $94 \%$ reliable.

\subsubsection{Data's Transfer to SPSS}

In the study, firstly, data about demographic information of the participants and their thoughts about music lesson were put into SPSS and frequency and percentage analyzes were made and distributions were determined. After the metaphors produced for the concept of "Music" were categorized, all data were transferred to the computer and coded according to the form number in the SPSS program. In the statistical calculations, the frequency and percentage analysis of the metaphors and the participants according to the distribution of the category were determined. In addition, in order to determine the metaphors according to gender, class and preferred music genre variables, Crosstabs were used and differences were tested according to $p=.05$ significant level by using Pearson Chi-Square test. The results were tabulated and interpreted accordingly.

\section{Results}

In this section, the findings related to the research questions were given and answers to these questions were sought.

\subsection{Findings About Music and Music Lesson}

Table 4. Students' level of liking to listen to music

\begin{tabular}{lcc}
\hline Options & f & \% \\
\hline I don't like at all & 13 & 1.3 \\
I like very little & 42 & 4.2 \\
I partially like & 148 & 14.7 \\
I like much & 249 & 24.8 \\
I greatly like & 551 & 54.9 \\
\hline Total & $\mathbf{1 0 0 3}$ & $\mathbf{1 0 0}$
\end{tabular}

As seen in Table 4, the majority of participants (800 participants with a rate of 79.7\%) liked to listen to music, while only a small number (55 participants with a rate of 5.5\%) did not. 148 participants stated that they like to listen to music partially. 
Table 5. Students' level of liking to music lesson

\begin{tabular}{lcc}
\hline Options & f & \% \\
\hline I don't like at all & 55 & 5.4 \\
I like very little & 67 & 6.6 \\
I partially like & 180 & 17.9 \\
I like much & 200 & 20.0 \\
I greatly like & 501 & 50.1 \\
\hline Total & $\mathbf{1 0 0 3}$ & $\mathbf{1 0 0}$
\end{tabular}

As seen in Table 5, the majority of participants (701 participants with a rate of $70.1 \%$ ) liked the music course, while only a few (122 participants with a rate of $12 \%$ ) did not. 180 participants with a rate of $17.9 \%$ expressed that they like music.

Table 6. The opinions related to the sufficiency of music lesson hours

\begin{tabular}{lcc}
\hline Options & $\mathbf{f}$ & $\%$ \\
\hline I think it is not sufficient & 271 & 27.1 \\
I think it is a bit sufficient & 120 & 11.9 \\
I think it is partially sufficient & 169 & 16.8 \\
I think it is highly sufficient & 88 & 8.7 \\
I think it is completely sufficient & 355 & 35.5 \\
\hline Total & $\mathbf{1 0 0 3}$ & $\mathbf{1 0 0}$ \\
\hline
\end{tabular}

As it is seen in Table 6, some of the participants (443 participants with a rate of $44.2 \%$ ) found the music lesson hours sufficient, whereas the participants (169 participants with a rate of 16.8\%) thought it was partially sufficient and a large number of them (391 participants with a rate of 39\%) stated that music lessons were not enough.

Table 7. The opinions about the desire to choose music as a profession

\begin{tabular}{lcc}
\hline Opinions & $\mathbf{f}$ & \% \\
\hline I don't want at all. & 310 & 30.9 \\
I want a little. & 173 & 17.2 \\
I want partially & 249 & 24.8 \\
I highly want & 116 & 11.5 \\
I certainly want & 153 & 15.3 \\
The ones who provided no answers & 2 & 0.2 \\
\hline Total & $\mathbf{1 0 0 3}$ & $\mathbf{1 0 0}$
\end{tabular}

In Table 7 it is seen that as well as participants who partially want to perform music as a profession (249 participants with a rate of $24.8 \%$ ), the majority of participants (483 participants with a rate of $48.1 \%$ ) expressed positive or negative opinions and stated that they have no intention of choosing music for their future career, a low number of participants (269 participants with a rate of $26.8 \%$ ) think of performing music as a career.

When the findings of this study are analyzed as well as the previous findings, it is possible to point out that the participants like music and music lessons, but their perceptions are negatively affected due to a considerably negative perception regarding music and music lesson in our society and they also have a negative approach towards choosing music for their future career in parallel with this negativity. 
Table 8. Types of music preferred by the participants

\begin{tabular}{lcc}
\hline Music Type & f & \% \\
\hline Turkish Folk Music (THM) & 292 & 14.6 \\
Turkish Classical Music (TSM) & 134 & 6.7 \\
Classical Music & 116 & 5.9 \\
Pop Music (Domestic and Foreign)) & 697 & 34.8 \\
Rock Music (Domestic and Foreign)) & 156 & 7.8 \\
Jazz Music (Domestic and Foreign)) & 55 & 2.7 \\
Rap Music (Domestic and Foreign) & 318 & 15.9 \\
Arabesque Music & 217 & 10.8 \\
All & 3 & 0.1 \\
Hip Hop & 6 & 0.3 \\
Ethnic Music & 6.1 \\
Sufi Music & 2 & 0.1 \\
I'm not listening & 5 & 0.2 \\
\hline
\end{tabular}

\section{Total}

In Table 8, the multiple responses to the question regarding which genre of music the participants prefer to listen to indicate that, the majority preferred to listen to pop music; other majority of participants preferred to listen to Turkish music genre including THM, TSM and Arabesque music; in the third rank, the preferred music genre is Rap music; After these genres, Rock music, Classical Music and Jazz were preferred and other music genres were slightly preferred. 


\subsection{Findings about Mehaphors Related to Music Concept}

Table 9. The distribution of metaphors developed for perceptions related to music concept

\begin{tabular}{|c|c|c|}
\hline Metaphors & & \\
\hline Positive Metaphors & $\mathbf{f}$ & $\%$ \\
\hline 1. Friend & 147 & 14.6 \\
\hline 2. Love & 101 & 10.1 \\
\hline 3. Affection & 81 & 8.1 \\
\hline 4. Spritiual relief & 72 & 7.1 \\
\hline 5. Life & 66 & 6.5 \\
\hline 6. An object I like & 50 & 5.0 \\
\hline 7. Entertainment & 48 & 4.8 \\
\hline 8. Poem & 44 & 4.4 \\
\hline 9. Beauty & 39 & 3.9 \\
\hline 10. Sibling & 33 & 3.3 \\
\hline 11. Peace & 31 & 3.1 \\
\hline 12. Happiness & 27 & 2.7 \\
\hline 13. Water & 25 & 2.5 \\
\hline 14. Everything & 23 & 2.3 \\
\hline 15. Art & 16 & 1.6 \\
\hline 16. Joy & 14 & 1.4 \\
\hline 17. Healing the Soul & 13 & 1.3 \\
\hline 18. Pal & 10 & 1.0 \\
\hline 19. Life Style & 10 & 1.0 \\
\hline 20. Passion & 9 & 0.9 \\
\hline 21. Source of life & 8 & 0.8 \\
\hline 22. Pleasure & 7 & 0.7 \\
\hline 23. Energy drink & 6 & 0.6 \\
\hline 24. Father & 6 & 0.6 \\
\hline 25. Nature & 6 & 0.6 \\
\hline 26. Memories & 5 & 0.5 \\
\hline 27. Meaning of life & 5 & 0.5 \\
\hline 28. Mother & 4 & 0.4 \\
\hline 29. Instrument & 4 & 0.4 \\
\hline 30. My world & 3 & 0.3 \\
\hline 31. Medicine & 3 & 0.3 \\
\hline 32. Nostalgia & 3 & 0.3 \\
\hline 33. Freedom & 3 & 0.3 \\
\hline 34. Rest one's head & 3 & 0.3 \\
\hline 35. Game & 2 & 0.2 \\
\hline 36. Family & 2 & 0.2 \\
\hline 37. Nightingale chirping & 2 & 0.2 \\
\hline 38. Classic music & 1 & 0.1 \\
\hline 39. Hope & 1 & 0.1 \\
\hline 40. Tale & 1 & 0.1 \\
\hline 41. Action & 1 & 0.1 \\
\hline 42. Sun & 1 & 0.1 \\
\hline 43. Legend & 1 & 0.1 \\
\hline 44. Excitement & 1 & 0.1 \\
\hline 45. Pencil & 1 & 0.1 \\
\hline 46. A magical sound & 1 & 0.1 \\
\hline 47. Enthusiasm & 1 & 0.1 \\
\hline 48. Culture & 1 & 0.1 \\
\hline 49. Life philosophy & 1 & 0.1 \\
\hline 50. Relaxing massage & 1 & 0.1 \\
\hline 51. Stress wheel & 1 & 0.1 \\
\hline 52. Talent & 1 & 0.1 \\
\hline 53. Pyschological balance & 1 & 0.1 \\
\hline 54. Concentration & 1 & 0.1 \\
\hline 55. Need & 1 & 0.1 \\
\hline 56. Aesthetics & 1 & 0.1 \\
\hline 57. Salt of soup & 1 & 0.1 \\
\hline 58. Breath & 1 & 0.1 \\
\hline Total & 952 & 94.9 \\
\hline Negative metaphors & $\mathbf{f}$ & $\%$ \\
\hline 59. Something ordinary & 19 & 1.9 \\
\hline 60. Something I don't like & 8 & 0.8 \\
\hline 61. Something meaningless & 7 & 0.7 \\
\hline 62. Melancholy & 5 & 0.5 \\
\hline 63 . Just a lesson & 3 & 0.3 \\
\hline 64. Something boring & 3 & 0.3 \\
\hline 65. A dark room & 2 & 0.2 \\
\hline 66. Stress & 2 & 0.2 \\
\hline 67. Not my interest & 1 & 0.1 \\
\hline 68. Idle class & 1 & 0.1 \\
\hline Total & 51 & 5.1 \\
\hline Final total & 1003 & 100 \\
\hline
\end{tabular}

In Table 9 it is seen that in accordance with the rankings and frequency and percentage distributions of the metaphors that the participants formed in their perceptions about the concept of "Music ", 1003 participants produced 68 valid metaphors, 58 of which were positive and 10 of which were negative. It is possible to note that there is a wide variety in terms of metaphors; the most frequently produced positive metaphors are Friend, Love, Affection, Spiritual Relief and 
Life; the most common negative metaphors are Something Trivial, Something I do not like, Something Futile and Meaningless and Melancholy.

Based on this finding, they found that the majority of the students have found the value of their inner expression by integrating music and thus music lessons in the concept of "Music". However, it is possible to state that some students tend to ignore and not to appreciate music and music based on the negative approach in society.

\subsection{Findings about Categories in which Metaphors Related to Music Concept Are Explained}

The metaphors they developed in accordance with Table 10 are classfied under 13 categories in terms of their common characteristics. Each metaphor is grouped according to the explanations made by the participants in the context of the metaphor. 
Table 10. The distribution of metaphors related to music concept according to categories

\begin{tabular}{|c|c|c|c|c|c|}
\hline \multirow{2}{*}{\multicolumn{2}{|c|}{ The name of category }} & \multirow{2}{*}{ Metaphors } & \multicolumn{2}{|c|}{ Metaphors produced in category } & \multirow{2}{*}{$\begin{array}{c}\text { Percent of produced total } \\
\text { metaphors }(\%)\end{array}$} \\
\hline & & & $\mathbf{f}$ & $\%$ & \\
\hline & & Memories & 5 & 2.0 & 0.5 \\
\hline & & Love & 101 & 41.4 & 10.1 \\
\hline & & Pencil & 1 & 0.5 & 0.1 \\
\hline 1 & Mucic as a means of eyprecsing emotions & Nostalgia & 3 & 1.2 & 0.3 \\
\hline 1 & Music as a means of expressing emotions & Affection & 81 & 33.2 & 8.1 \\
\hline & & Poem & 44 & 18.0 & 4.4 \\
\hline & & Passion & 9 & 3.7 & 0.9 \\
\hline & & Total & 244 & 100 & 24.4 \\
\hline & & Friend & 147 & 93.6 & 14.6 \\
\hline 2 & Music as a means of removing loneliness & Pal & 10 & 6.4 & 1.0 \\
\hline & & Total & 157 & 100 & 15.6 \\
\hline & & Nightingale chirping & 2 & 1.5 & 0.2 \\
\hline & & Nature & 6 & 4.5 & 0.6 \\
\hline & & Peace & 31 & 22.8 & 3.1 \\
\hline & & Rest One's Head & 3 & 2.2 & 0.3 \\
\hline & & Classic Music & 1 & 0.7 & 0.1 \\
\hline & & Concentration & 1 & 0.7 & 0.1 \\
\hline 3 & Music as a means of meditation & Pyschological Balance & 1 & 0.7 & 0.1 \\
\hline 3 & Music as a means of meditation & Relaxing Massage & 1 & 0.7 & 0.1 \\
\hline & & Spiritual Relief & 72 & 52.9 & 7.1 \\
\hline & & Healing the Soul & 13 & 9.7 & 1.3 \\
\hline & & A magical sound & 1 & 0.7 & 0.1 \\
\hline & & Stress Wheel & 1 & 0.7 & 0.1 \\
\hline & & Water & 3 & 2.2 & 0.3 \\
\hline & & Total & 136 & 100 & 13.5 \\
\hline & & My world & 3 & 2.2 & 0.3 \\
\hline & & Sun & 1 & 0.7 & 0.1 \\
\hline & & Life & 66 & 49.3 & 6.5 \\
\hline & & Life Philosophy & 1 & 0.7 & 0.1 \\
\hline 4 & Music as a Source of Life & Everything & 23 & 17.2 & 2.3 \\
\hline & & Water & 22 & 16.4 & 2.2 \\
\hline & & Source of Life & 8 & 6.0 & 0.8 \\
\hline & & Life Style & 10 & 7.5 & 1 \\
\hline & & Total & 134 & 100 & 13.3 \\
\hline & & Enthusiasm & 1 & 1.0 & 0.1 \\
\hline & & Entertainment & 48 & 48.5 & 4.8 \\
\hline & & Tale & 1 & 1.0 & 0.1 \\
\hline 5 & Music as an Element of Happiness and & Happiness & 27 & 27.3 & 2.7 \\
\hline 5 & Pleasure & Joy & 14 & 14.1 & 1.4 \\
\hline & & Hope & 1 & 1.0 & 0.1 \\
\hline & & Pleasure & 7 & 7.1 & 0.7 \\
\hline & & Total & 99 & 100 & 9.9 \\
\hline & & Aesthetics & 1 & 1.8 & 0.1 \\
\hline & & Beauty & 39 & 68.3 & 3.9 \\
\hline 6 & Music as Aesthetics & Culture & 1 & 1.8 & 0.1 \\
\hline & & Art & 16 & 28.1 & 1.6 \\
\hline & & Total & 57 & 100 & 5.7 \\
\hline & & Instrument & 4 & 7.4 & 0.4 \\
\hline 7 & Music as an Important Item & An object I like & 50 & 92.6 & 5.0 \\
\hline & & Total & 54 & 100 & 5.4 \\
\hline & & Idle class & 1 & 2.0 & 0.1 \\
\hline & & Something meaningless & 7 & 13.7 & 0.7 \\
\hline & & Melancholy & 5 & 9.8 & 0.5 \\
\hline & & Not my interest & 1 & 2.0 & 0.1 \\
\hline & & A dark room & 2 & 3.9 & 0.2 \\
\hline 8 & Music as a trivial and disturbing element & Just a lesson & 3 & 5.9 & 0.3 \\
\hline & & Something I don't like & 8 & 15.7 & 0.8 \\
\hline & & Something boring & 3 & 5.9 & 0.3 \\
\hline & & Something ordinary & 19 & 37.2 & 1.9 \\
\hline & & Stress & 2 & 3.9 & 0.2 \\
\hline & & Total & 51 & 100 & 5.1 \\
\hline & & Family & 2 & 4.2 & 0.2 \\
\hline & & Mother & 4 & 8.3 & 0.4 \\
\hline 0 & & Father & 6 & 12.5 & 0.6 \\
\hline 9 & Music as an indispensable element & Sibling & 33 & 68.7 & 3.3 \\
\hline & & Freedom & 3 & 6.3 & 0.3 \\
\hline & & Total & 48 & 100 & 4.8 \\
\hline & & Salt of soup & 1 & 9.1 & 0.1 \\
\hline & & Meaning of life & 5 & 45.5 & 0.5 \\
\hline & & Need & 1 & 9.1 & 0.1 \\
\hline 10 & Music as a need & Medicine & 3 & 27.2 & 0.3 \\
\hline & & Breath & 1 & 9.1 & 0.1 \\
\hline & & Total & 11 & 100 & 1.1 \\
\hline & & Action & 1 & 10.0 & 0.1 \\
\hline & & Energy drink & 6 & 60.0 & 0.6 \\
\hline 11 & Music as an energy factor & Excitement & 1 & 10.0 & 0.1 \\
\hline & & Game & 2 & 20.0 & 0.2 \\
\hline & & Total & 10 & 100 & 1.0 \\
\hline & & Talent & 1 & 100.0 & 0.1 \\
\hline 12 & Music as a talent & Total & 1 & 100 & 0.1 \\
\hline & Music as an element that leads to & Legend & 1 & 100 & 0.1 \\
\hline 13 & imagination & Total & 1 & 100 & 0.1 \\
\hline & Final total of met & hors & 1003 & 100 & 100 \\
\hline
\end{tabular}

\subsubsection{Category 1: Music as a Means of Expressing Emotions}

When Table 10 is examined, it is seen that the category "Music as a means of expressing emotions" consists of 7 metaphors and 244 participants. When the frequency distributions of the metaphors in this category are examined, the 
most commonly used metaphor is "Love"; "Affection" and "Poem" are the second and third metaphors most frequently repeated in this category. Following each category, the examples of justification given by participants regarding why they developed these metaphors in that category are as follows:

"Music is like love. Because it reminds me of feelings and loved ones." (Participant 568)

"Music is like love. Because it will make my heart beat like it does in love." (Participant 221)

"Music is like poem. Because, in order to express emotions in poem, the words take every form of emotion just as the voices take all kinds of emotions." (Participant 442)

"Music is like a passion. Because I am passionate about music as we are passionately bound to someone." (Participant 927)

"Music is like memories. Because when I listen to music, I remember the past." (Participant 903)

"Music is like nostalgia. Because when I listen to music, I think of my feelings in the old days." (Participant 309)

"Music is like a pencil. Because the emotions in music in the same way as we convey emotions in the paper with the pen." (Participant 711)

\subsubsection{Category 2: Music as a Means of Removing Loneliness and Being Confident}

When the Table 10 is examined, it is seen that the category "Music as a tool that removes loneliness and being confident" consists of 2 metaphors and 157 participants. When the frequency distributions of the metaphors in this category are examined, the most commonly used metaphor is the "Friend" and the "Pal" is the second most frequently repeated metaphor in this category. Following each category, the examples of justification given by participants regarding why they developed these metaphors in that category are as follows:

"Music is like a friend. Because he will not leave you alone, and in good days and bad days will be the ointment to the wound." (Participant 747)

"Music is like a pal. Because when I listen to music, I feel as if my friend listens to my secrets." (Participant 15)

\subsubsection{Category 3: Music as a Means of Meditation}

When Table 8 is examined, it is seen that the category "Music as a means meditation" consists of 13 metaphors and 136 participants. When the frequency distributions of the metaphors in this category are considered, the most commonly used metaphor is "Spiritual relief" while "Peace" and "Healing the Soul" metaphors are the second and third metaphors in this category. Following each category, the examples of justification given by participants regarding why they developed these metaphors in that category are as follows:

"Music is like spiritual relief. Because it helps me forget the troubles of real life and therefore takes my stress away." (Participant 755)

"Music is like peace. Because when I listen, I always have a good feeling of peace by turning a bad thing I experience into a good one." (Participant 981)

"Music is like healing the soul. Because the soul reaches the peace by being fed with music." (Participant 259)

"Music is like nature. Because when I listen to sounds like the ones in nature, it relaxes me." (Participant 651)

"Music is like rest one's head. Because it gives comfort and peace to the person." (Participant 22)

"Music is like water. Because it relaxes people like water does." (Participant 709)

"Music is like a nightingale chirping. Because when I listen, it rests my soul like a nightingale chirping." (Participant 601)

"Music is like classic music. Because classic music rests the soul." (Participant 8)

"Music is like concentration. Because when I listen while studying, I can focus more on my lessons." (Participant 268)

"Music is like a psychological balance. Because it will relieve us by restoring our psychology." (Participant 463)

"Music is like a relaxing massage. Because I'm comfortable listening." (Participant 6)

"Music is like a magical sound. Because it will fascinate me by enchanting me." (Participant 374)

"Music is like a stress wheel. Because when I listen, it calms me down." (Participant 49)

\subsubsection{Category 4: Music as a Life Source}

When the Table 10 is examined, it is seen that the category "Music as a source of life" consists of 8 metaphors and 134 participants. When the frequency distribution of the metaphors in this category are examined, the most commonly used 
metaphor is "Life"; "Everything" and "Water" are the second and third metaphors most frequently repeated in this category. Following each category, the examples of justification given by participants regarding why they developed these metaphors in that category are as follows:

"Music is like spiritual relief. Because it takes me away from the troubles of real life and relaxes me" (Participant 755)

"Music is like life. Because I can't live without listening to music." (Participant 220)

"Music is like everything. Because for me, it is related to everything in my life." (Participant 138)

"Music is like water. Because just as there is no life without water, there is no life without music." (Participant 542)

"Music is like a life style. Because it affects every area of my life." (Participant 569)

"Music is a source of life. Because it gives a meaning to my life by changing my perspective on life." (Participant 159)

"Music is like my world. Because it gives me the joy and reason to live." (Participant 270)

"Music is like the sun. Because it provides life with its shines." (Participant 291)

"Music is like a life philosophy. Because it gives me reason to live." (Participant 218)

3.3.5 Category 5: Music as an Element of Happiness and Pleasure

When Table 10 is examined, it is seen that the category "Music as an element of happiness and pleasure" consists of 7 metaphors and 99 participants. When the frequency distributions of the metaphors in this category are examined, it is observed that the most commonly used metaphor is "Entertainment", while "Happiness" and "Joy" are the second and third metaphors most frequently repeated in this category. Following each category, the examples of justification given by participants regarding why they developed these metaphors in that category are as follows:

"Music is like entertainment. Because music makes an unhappy person happy." (Participant 225)

"Music is like happiness. Because it makes my face laugh, corrects my spirits, revives me." (Participant 73)

"Music is like joy. Because it pleases me." (Participant 558)

"Music is like pleasure. Because when I listen to it, I like it and it makes me pleased." (Participant 215)

"Music is like enthusiasm. Because it makes me fidget." (Participant 194)

"Music is like a tale. Because when I listen, I'll dive to other realms like a fairy tale." (Participant 18)

"Music is like hope. Because when I listen to it, I hope and enjoy." (Participant 14)

3.3.6 Category 6: Music as Aesthetics

When Table 10 is examined, it is seen that the category "Music as aesthetics" consists of 4 metaphors and 57 participants. When the frequency distributions of the metaphors in this category are examined, it is observed the most commonly used metaphor is "Beauty" and while the metaphors "Art" is the second most frequently repeated metaphor in this category. Following each category, the examples of justification given by participants regarding why they developed these metaphors in that category are as follows:

"Music is like beauty. Because it evokes everything that is beautiful to me." (Participant 1)

"Music is like an art. Because it is very aesthetic to me like every branch of art." (Participant 587)

"Music is like aesthetics. Because it is art." (Participant 42)

"Music is like culture. Because it represents our culture with art." (Participant 153)

\subsubsection{Category 7: Music as an Important Item}

When Table 10 is examined, it is seen that the category "Music as an important item" consists of 2 metaphors and 54 participants. When the frequency distributions of the metaphors in this category are examined, it is seen that the most commonly used metaphor is "An Object I Like". Following each category, the examples of justification given by participants regarding why they developed these metaphors in that category are as follows:

"Music is like an object I like. Because I find music and music instruments important and I like them." (Participant 720)

"Music is like a musical instrument. Because I love the flute so much and I can't make music without it." (Participant 288)

3.3.8 Category 8: Music as a Trivial and Disturbing Element

When Table 10 is examined, it is seen that the category "Music as a trivial and disturbing element" consists of 10 
metaphors and 51 participants. When we look at the frequency distributions of the metaphors in this category, we see that the most commonly used metaphor is "Something trivial", while the metaphors" Something I don't like" and "Something meaningless" are the second and third metaphors that are frequently repeated in this category. Following each category, the examples of justification given by participants why they developed these metaphors in that category are as follows:

"Music is like something ordinary. Because music sounds ridiculous to me." (Participant 112)

"Music is like something I don't like. Because I don't have much talent." (Participant 363)

"Music is like something meaningless. Because I don't like it." (Participant 136)

"Music is like a melancholy. Because when I listen, it depresses me." (Participant 471)

"Music is just like a lesson. Because for me, it's no different than other lessons, I don't care much." (Participant 16)

"Music is like something boring. Because I'm bored because I can't do it." (Participant 534)

"Music is like a dark room. Because I can't play and get stressed." (Participant 510)

"Music is like an idle class. Because it makes sense to me." (Participant 828)

"Music isn't like my interest. Because I'm not interested." (Participant 195)

3.3.9 Category 9: Music as an Indispensable Element

When Table 10 is examined, it can be seen that the category "Music as an indispensable element" consists of 5 metaphors and 48 participants. When the frequency distributions of the metaphors in this category are examined, it is seen that the most commonly used metaphor is "Sibling". Following each category, the examples of justification given by participants regarding why they developed these metaphors in that category are as follows:

"Music is like sibling. Because it is indispensable, it is with me everywhere and adds color to my life." (Participant 536)

"Music is like a father. Because I listen to music whenever I miss my father." (Participant 710)

"Music is like a mother. Because I have devoted my life to music like my mom." (Participant 178)

"Music is like freedom. Because I can't give up my music as I can't give up my freedom." (Participant 51)

"Music is like family. Because music is like family." (Participant 539)

3.3.10 Category 10: Music as a Need

When Table 10 is examined, it is indicated that the category "Music as a need" consists of 5 metaphors and 11 participants. When the frequency distribution of metaphors in this category are examined, it is observed that the most commonly used metaphors are "Meaning of Life" and "Medicine". Following each category, the examples of justification given by participants regarding why they developed these metaphors in that category are as follows:

"Music is like the meaning of life. Because it is as important as life and is what we need." (Participant 68)

"Music is like medicine. Because, when we get sick, just as we need medication to heal, so the soul needs music." (Participant 355)

"Music is like salt of soup. Because it adds flavor to our lives like the flavor it adds to the soup." (Participant 405)

"Music is like a need. Because, like other needs of man, it is a vital necessity." (Participant 275)

"Music is like breathing. Because it is impossible to live without music in the manner that it is to live without breath." (Participant 769)

\subsubsection{Category 11: Music as an Energy Factor}

When the Table 10 is examined, it is seen that the category "Music as an energy factor" consists of 4 metaphors and 10 participants. When the frequency distribution of metaphors in this category are examined, it is seen that the most commonly used metaphor is "Energy Drink". Following each category, the examples of justification given by participants regarding why they developed these metaphors in that category are as follows:

"Music is like an energy drink. Because I work twice faster when I normally listen to music." (Participant 33)

"Music is like a game. Because when I listen to music, I feel energized just like in a game." (Participant 20)

"Music is like an action. Because I save energy by discovering the actions in the songs I listen to." (Participant 217)

"Music is like excitement. Because when I listen, I get excited, and my heart wiggles." (Participant 552) 


\subsubsection{Category 12: Music as a Talent}

When Table 10 is examined, it is seen that the category "Music as a talent" consists of totally 1 metaphor and 1 participant. After each category, the example belonging to the justifications which the participants develop the metaphors forming that category is as follows.

"Music is like an talent. Because neither a song can be sung nor an instrument can be played without talent." (Participant 606)

\subsubsection{Category 13: Music as an Element That Leads to Imagination}

When Table 10 is examined, it is seen that the category "Music as an element that leads to imagination" consists of totally 1 metaphor and 1 participant. After each category, the example belonging to the justifications which the participants develop the metaphors forming that category is as follows.

"Music is like a legend. Because, when I listen to music I feel as if I were in the world of the dreams." (Participant 113)

3.4 Findings about the Differences in Regard to Certain Variables on the Basis of the Category of Produces Metaphors

3.4.1 Differences in Regard to Gender Variable

Table 11. Cognitive categories' differences in terms of gender variables

\begin{tabular}{lccc}
\hline \multirow{2}{*}{ Categories } & \multicolumn{2}{c}{ Gender } & \multirow{2}{*}{ Total } \\
\cline { 2 - 3 } & Girl & Boy & \\
\hline Music as a means of expressing emotions & 103 & 141 & 244 \\
Music as a means of removing loneliness and being confident & 90 & 67 & 157 \\
Music as a means of meditation & 70 & 66 & 136 \\
Music as a source of life & 62 & 72 & 134 \\
Music as an element of happiness and pleasure & 61 & 38 & 99 \\
Music as aesthetics & 31 & 26 & 57 \\
Music as an important item & 23 & 31 & 54 \\
Music as a trivial and disturbing element & 23 & 28 & 51 \\
Music as an indispensable element & 24 & 24 & 48 \\
Music as a need & 6 & 5 & 11 \\
Music as an energy factor & 5 & 5 & 10 \\
Music as a talent & 0 & 1 & 1 \\
Music as an element that leads to imagination & 1 & 0 & 1 \\
\hline Total & $\mathbf{4 9 9}$ & $\mathbf{5 0 4}$ & $\mathbf{1 0 0 3}$ \\
\hline
\end{tabular}

As seen in Table 11, 13 cognitive categories are compared in regard to gender variable. In line with these findings, it can be said that the girl and the boy students have different perceptions about "the music concept" $\left(\chi_{67}^{2}=2,862.838, p\right.$ $=.00)$. So, when looked at the variables, it showed the difference,

- The boy students produced the metaphor "love" in the category "music as a means of expressing emotions", the metaphor "healing the soul" in the category "music as a means of meditation", the metaphors "life" and "life style" in the category "music as a source of life", the metaphor "an object I like" in the category "music as an important item" more than the girl students did.

- The girl students produced the metaphor "friend" in the category "music as a means of removing loneliness and being confident", the metaphors "peace" and "spiritual relief" in the category "music as a means of meditation", the 
metaphor "water" in the category "music as a source of life", the metaphors "entertainment" and "happiness" in the category "music as a means of happiness and pleasure" more than the boy students.

- The other metaphors in the categories were produced by girl and boy students equally.

3.4.2 Differences in Regard to Class Variable

Table 12. Cognitive categories' differences in regard to class variables

Categories

Grade

5. grade 6. grade 7 . grade 8 . grade

Total

\begin{tabular}{|c|c|c|c|c|c|}
\hline Music as a means of expressing emotions & 70 & 69 & 63 & 42 & 244 \\
\hline Music as a means of removing loneliness and being confident & 42 & 55 & 36 & 24 & 157 \\
\hline Music as a means of meditation & 18 & 51 & 30 & 37 & 136 \\
\hline Music as a source of life & 33 & 40 & 32 & 29 & 134 \\
\hline Music as an element ofhappiness and pleasure & 28 & 31 & 23 & 17 & 99 \\
\hline Music as aesthetics & 11 & 20 & 16 & 10 & 57 \\
\hline Music as an important item & 26 & 14 & 6 & 8 & 54 \\
\hline Music as a trivial and disturbing element & 11 & 13 & 14 & 13 & 51 \\
\hline Music as an indispensable element & 12 & 19 & 10 & 7 & 48 \\
\hline Music as a need & 3 & 4 & 4 & 0 & 11 \\
\hline Music as an energy factor & 3 & 2 & 3 & 2 & 10 \\
\hline Music as a talent & 0 & 1 & 0 & 0 & 1 \\
\hline Music as an element that leads to imagination & 0 & 0 & 1 & 0 & 1 \\
\hline Total & 257 & 322 & 235 & 189 & 1003 \\
\hline \multirow{2}{*}{ Pearson Chi-Square } & \multicolumn{2}{|c|}{ Value } & \multicolumn{2}{|c|}{ df } & $\mathbf{p}$ \\
\hline & \multicolumn{2}{|c|}{$9,530.211$} & \multicolumn{2}{|c|}{201} & .00 \\
\hline
\end{tabular}

As seen in Table 12, 13 cognitive categories are compared in regard to class variable. In line with these findings, it can be said that the classes' perceptions about the concept "music" differ from each other $\left(\chi_{201}^{2}=9,530.211, p=.00\right)$. So, when looked at the variables, it signifies difference,

- The fifth-grade students produced the metaphors "poem" and "passion" in the category "Music as a means of expressing emotions", the sixth grades produced the metaphor "love" and the seventh grades produced the metaphor "affection" more than the other ones.

- The sixth grades produced the metaphor "friend" in the category "Music as a means of removing loneliness and being confident" produced more than the other ones.

- The sixth grades produced the metaphors "peace"" and "nature" in the category "Music as a means of meditation", the eigth grades produced the metaphors "water", "spiritual relief" and "healing the soul" in the same category more than the other ones.

- The sixth grades produced the metaphor "life" in the category "Music as a source of life" produced more than the other ones.

- The fifth and sixth grades produced the metaphor "entertainment" in the category "Music as a means of happiness and pleasure" and the seventh grades produced the metaphor "happiness" in the same category more than the other ones.

- The sixth grades produced the metaphor "art" in the category "Music as aesthetics" more than the other ones.

- The fifth grades produced the metaphor "an object I like" in the category "Music as an important item" more than the other ones. 
- The sixth grades produced the metaphor "sibling" in the category "Music as an indispensable element" more than the other ones. The other metaphors in the categories were produced equally.

\subsubsection{Differences in Regard to the Preferred Music Kind}

Table 13. Difference of cognitive categories in regard to the preferred music kind variable

Categories Music Kinds (Multiple Response)

\begin{tabular}{|c|c|c|c|c|c|c|c|c|c|c|c|c|c|}
\hline & THM & TSM & Classic & Pop & Rock & Jazz & Rap & Irabesque & All & $\begin{array}{l}\text { Hip } \\
\text { Hop }\end{array}$ & thnic & Sufi & Total \\
\hline $\begin{array}{l}\text { Music as a means of expressing } \\
\text { emotions }\end{array}$ & 82 & 40 & 27 & 180 & 37 & 14 & 78 & 52 & 0 & 0 & 0 & 0 & 244 \\
\hline $\begin{array}{l}\text { Music as a means of removing } \\
\text { loneliness and being confident }\end{array}$ & 39 & 26 & 20 & 116 & 21 & 4 & 52 & 32 & 2 & 4 & 1 & 0 & 157 \\
\hline Music as a means of meditation & 41 & 23 & 17 & 99 & 20 & 11 & 49 & 38 & 0 & 1 & 0 & 2 & 136 \\
\hline Music as a source of life & 42 & 11 & 5 & 88 & 16 & 5 & 39 & 15 & 0 & 1 & 1 & 0 & 134 \\
\hline $\begin{array}{l}\text { Music as an element of happiness } \\
\text { and pleasure }\end{array}$ & 31 & 12 & 8 & 75 & 30 & 9 & 33 & 12 & 1 & 0 & 0 & 2 & 99 \\
\hline Music as aesthetics & 2 & 3 & 21 & 23 & 10 & 1 & 11 & 2 & 0 & 0 & 0 & 0 & 57 \\
\hline Music as an important item & 23 & 9 & 9 & 47 & 8 & 4 & 23 & 12 & 0 & 0 & 0 & 0 & 54 \\
\hline $\begin{array}{l}\text { Music as a trivial and disturbing } \\
\text { element }\end{array}$ & 7 & 7 & 3 & 22 & 4 & 4 & 17 & 29 & 0 & 0 & 0 & 0 & 51 \\
\hline Music as an indispensable element & 16 & 3 & 3 & 33 & 9 & 2 & 12 & 18 & 0 & 0 & 0 & 1 & 48 \\
\hline Music as a need & 5 & 0 & 0 & 5 & 0 & 0 & 0 & 3 & 0 & 0 & 0 & 0 & 11 \\
\hline Music as an energy factor & 4 & 0 & 2 & 7 & 1 & 1 & 4 & 3 & 0 & 0 & 0 & 0 & 10 \\
\hline Music as a talent & 0 & 0 & 1 & 1 & 0 & 0 & 0 & 0 & 0 & 0 & 0 & 0 & 1 \\
\hline $\begin{array}{l}\text { Music as an element that leads to } \\
\text { imagination }\end{array}$ & 0 & 0 & 0 & 1 & 0 & 0 & 0 & 1 & 0 & 0 & 0 & 0 & 1 \\
\hline Total & 292 & 134 & 116 & 697 & 156 & 55 & 318 & 217 & 3 & 6 & 2 & 5 & $2002 / 1003$ \\
\hline \multicolumn{4}{|c|}{ Pearson Chi-Square } & \multicolumn{4}{|c|}{ Value } & \multicolumn{2}{|l|}{ df } & \multicolumn{4}{|c|}{$\mathbf{p}$} \\
\hline
\end{tabular}

As seen in Table 13, 13 cognitive categories were compared in regard to the variable of kind of music which they prefer to listen to. In the direction of these findings, it can be said that the metaphors which are formed concerning with the concept "music" in regard to kinds of music differ from each other $\left(\chi_{451}^{2}=8,119.066, p=.00\right)$. So, when looked at the variables which made difference, it has been determined that:

- The participants who made the main difference in almost all of the categories and produced the most metaphors prefer to listen to pop music,

- The metaphors "love", "affection", and "poem" were produced in the category "Music as a means of expressing feelings", the most and the participants whose music preference is pop music made difference, and the other participants whose music preference is Rap, THM, TSM and Arabesque produced the most metaphors,

- The metaphor "friend" was produced in the category "Music as a means of removing loneliness and being a confident", the most and the participants whose music preference are pop music made difference, and the other participants whose music preference is Rap, THM, TSM and Arabesque produced the most metaphors,

- The metaphors "spiritual relief", "peace", and "healing the soul" were produced in the category "Music as a means of meditation", the most and the participants whose music preference are pop music made difference, and the other participants whose music preference is Rap, THM, TSM and Arabesque produced the most metaphors, 
- The metaphors "life", "everything", and "water" were produced in the category "Music as a source of life" the most and the participants whose music preference are pop music made differences, and the other participants whose music preference is Rap, THM, TSM and Arabesque produced the most metaphors,

- The metaphors "entertainment", "happiness", and "joy" were produced in the category "Music as a means of happiness and pleasure" the most and the participants whose music preference is pop music made difference, and the other participants whose music preference is Rap, THM, TSM and Arabesque produced the most metaphors,

- The metaphors "beauty" and "art" were produced in the category "Music as aesthetics" the most, and while the participants whose preference is pop music produced the metaphor "Beauty" the most, the ones whose preference is Classic Music produced the metaphor "art" the most.

- The metaphor "an object I like" was produced in the category "Music as an important item" the most and the participants whose music preference is pop music made difference, and the other participants whose music preference is Rap, THM, TSM and Arabesque produced the most metaphors,

- The metaphor "sibling" was produced in the category "Music as an indispensable element" the most and the participants whose music preference is pop music made difference, and the other participants whose music preference is Rap, THM, TSM and Arabesque produced the most metaphors,

- The participants whose music preference is only all kinds of music, Hip Hop Music and Ethnic Music and Sufi Music produced very few metaphors, didn't make any difference and besides, in the other categories, they didn't produce as many metaphors as to make difference.

\section{Discussion and Conclusion}

In the study, concerning with the approaches to music lesson, it has been concluded that most of the students like listening to music and music lesson, and do not find the music lesson hours enough and do not want to choose music as a profession in future. Parasiz's (2018) study titled "Secondary School Students' Music Taste and Their Expectations From Music Lesson" support the results which have been obtained in this study. In his study, Parasiz has inferred that the students like music and music lesson, do not find the music lesson hours enough and most of the students do not want to choose music as a profession.

As to the students who have a bad attitude to music and music lesson, it has been thought that this attitude results from the judgement that music and music lessons are considered to be "an unnecessary and trivial occupation" by our society.

When this conclusion is evaluated from the point of music education, it has been thought that the doings such as organizing music activities, including the students in these activities and giving a chance to express themselves, supporting the students with the extracurricular exercises will be effective so as to win every student and to endear the lesson to the students. In addition, with the aim of encouraging the students to choose music as a profession, it has been thought that the familiarisation trip to the schools which provide music training will open up the students' horizon.

As to music genres which the students prefer to listen to, it has been determined that the most preferred one is Pop Music, Rap is the most preferred after Pop Music, and according to the order of preference, THM, Arabesque, Rock, TSM, Classical Music and Jazz are listened by the most.The studies of Gür, Dalmış, Kırmızıdağ, Çelik, \&Boz (2012), Bayhan (2013) and Parasiz (2018) support the result of this study. In these studies, it has been ascertained that Pop Music is one that is listened by the most. Depending on this result, it has been thought that popular music should be benefited from music education more so as to catch the students' attention and increase attendance to the lessons and popular music should be given place to in music training books.

It has been determined that the secondary school students produce 58 positive and 10 negative, totally 68 metaphors. As to the metaphors which are produced by the most, it has been understood that they are "Friend" and "Love". When looked at the produced metaphors, it has been seen that most of the students integrate music and music lessons with their lives and they frequently use music with different aims such as expressing their feelings, sharing their loneliness, getting rid of their problems, being happy, reaching the beauty, living and getting energy. The studies of Umuzdaş \& Umuzdaş (2013), Babacan (2014), Yazıcı (2015), Acay Sözbir and Çamlıbel Çakmak (2016), Tez (2016), Açıkgöz (2017), Düzgören and Gerekten (2017), Dinç Altun and Muşmul (2018), Eren (2018), Gerekten and Barışeri Ahmethan (2018) and Uzunoğlu Yegul (2018) support this result which have been obtained.

Unlike the other studies, in this study the metaphor "Water" gets meaning in the categories both "Music as a means of meditation" and "Music as a source of life" mutually. Another difference is that the category "Music as a means of removing loneliness and being confident" is absent in the other studies and that the metaphors "Friend" and "Pal" which represent this category are under the category "Entertaining" in the studies of Umuzdaş \& Umuzdaş (2013) and under the category "Integrating, Unifying" in the study of Babacan (2014). 
Besides, the negative metaphors which are rarely seen in the other studies are another difference of this study. The category "Music as a trival and disturbing element" shows similarity to the category "Music lesson is boring" in the study of Babacan (2014). As to the produced negative metaphors, it can be said that they are produced depending on the judgement that music lesson is considered as "an unnecessary and trivial occupation" by our society.

In the study, unlike the other studies, it has been determined that the produced metaphors differ according to gender, class and music genre variables which are preferred to listen to. Accordingly, boy students give more importance to love, life, affection while girl students give more importance to the concepts such as friend, peace, happiness. At the class level, it has been determined that the fifth grades prioritise the concepts such as affection, feeling, entertainment; the sixth grades prioritise the concepts such as friend, sibling, peace, life and love; the seventh grades prioritise affection and happiness; the eighth grades prioritise peace and relaxation.

In addition, in the study, it has been determined that the metaphors which the students produced differ according to music genre they prefer to listen to. Accordingly, it has been ascertained that the genre in which the most metaphors are produced is Pop Music according to the students' music preference. It can be thought that the genre in which the most metaphors are produced is Pop Music, for it contains a lot of music genres such as Pop Music, THM, TSM, Arabesque, Jazz, Rap in itself at the present time.

The students have not preferred music such as Hip Hop, Etnic and Sufi Music and produced metaphors about them. Rap, THM, TSM and Arabesque are the music genres which the students have produced the most metaphors apart from Pop music. Especially in the category "Music as a trivial and boring element", the students who prefer to listen to Arabesque music produce the most metaphors because of the dreary, melancholic and rebelling structure of Arabesque music and this is an example of showing that the produced metaphors are directly related to music genre which is preferred to listen.

In music education, the teachers can use the metaphors as a means so as to determine the students' individual differences, ways of thinking and necessities which arise according to their genders and class levels. Depending on this, usage of metaphor can contribute to developing new teaching methods according to these individual differences with the aim of endearing music and creating positive behavioural change.

Music is naturally metaphoric because it is an intangible concept. Therefore, usage of metaphor in music education is very important in making the students understand what is wanted to be told and turning something intangible to something tangible. Music teachers can increase the students' motivation by making the classes more interesting through usage of metaphore, bring the students' opinions into the open and create a more effective and permanent atmosphere, provide the knowledge to be permanent by embodying the knowledge which is taught with other concepts, contribute the students' individual and social development and provide them to grow as a healthy person.

Additionally, music teachers can know their students better through metaphors by solving their subconcious thoughts about the lesson, bring their deficiencies and problems into the open and contribute to increase the importance and effect of music and especially the importance and effect of music lessons in the National Education by finding the clues to minimize the negative approach in the society.

As to this study and similar ones which will be carried out in future, they are thought to be effective in delivering the importance of music and music lesson so that the students can grow up as a healthy person sociologically and psychologically.

\section{References}

Acay, S. S., \& Çamlıbel, Ç. Ö. (2016). Metaphorical perceptions of pre-schoolo teacher candidates about music. The Journal of Academic Social Science Studies, 42, 269-282. https://doi.org/10.9761/JASSS3248

Açıkgöz, N. (2017). Research of metaphor models related to music lesson in secondary schools (Master's Thesis). Malatya: İnönü University Institute of Education Sciences. Online available from http://www.yok.gov.tr (Thesis No: 10177829).

Aydiner, U. M. (2015). The examining of teacher candidates' perception of turkish folk and traditional turkish art music through metaphors. Afyon Kocatepe University Academic Music Research Journal, 1(1), 59-76. https://doi.org/10.5578/AMRJ.8905

Babacan, E. (2014). AGSL Students' perception of music concept: metaphor analysis. Journal of Research in Education and Teaching, 3(1), 124-132. Online available from http://www.jret.org/FileUpload/ks281142/File/12.babacan.pdf

Balc1, A. (1999). Metaphorical images of school: school perceptions of students, teachers and parents from four selected schools in Ankara (Doctoral Dissertation). Ankara: Middle East Technical University. Online available from http://www.yok.gov.tr (Thesis No: 82164). 
Bayhan, V. (2013). Youth and postmodern identity patterns-sociological profile of university youth (Inonu University Case). Journal of Youth Research, 1(1), 134-157. Online available from http://dergipark. ulakbim.gov.tr/genader/article/view/5000047041/5000044331

Çelenk, K., \& Özşen, B. (2018). Measurement and evaluation of student performance during the stringed instrument training. In M. Keha \& Z. Alimgereyev (Eds.), $4^{\text {th }}$ International Congress on Vocational and Technical Sciences Full Text Book, 1, (pp. 491-508). Gaziantep: İksad Press.

Demirci, K. (2016). Metaphor: a narrative and production mechanism. In M. Sarıca \& B. Sarıca (Eds.), Linguictics Culture and Literature (pp. 330-343). Ankara: Padam Press.

Dinç, A. Z., \& Muşmul, E. (2018). Metaphoric perceptions of violin course trainers. About The Concept of Music, Online Journal of Music Sciences, 3(2), 46-62. https://doi.org/10.31811/ojomus.478908

Düzgören, H., \& Gerekten, S. E. (2017). Metaphorical perceptions of anatolian high school students about music course. Online Journal of Music Sciences, 2(3). Online available from https://dergipark. org.tr/download/article-file/398403

Eraslan, L. (2011). Sociological metaphors. Academic Sight International Refereed Online Journal, 27, 1-22.

Eren, B. (2018). The Metaphorical Perceptions of Special Education Teacher Candidates Regarding The Concept of Music, Turkish Studies, 13(19), 697-716, 2018. https://doi.org/10.7827/TurkishStudies.13929

Forceville, C. (2002). The identification of target and source in pictorial metaphors. Journal of Pragmatics, 34(1), 1-14. https://doi.org/10.1016/S0378-2166(01)00007-8

Fox, D. (1969). The research process in education. Holt: Rinehart Press.

Gerekten, S. E., \& Barışeri, A. N. (2018). Fine Arts High School Music Students' Perceptions About Concept of Turkish Folk Music. Journal of Erzincan Education Faculty, 20(2), 387-406. 10.17556/erziefd.334139

Gür S. B., Dalmış, İ., Kırmızıdağ, N., Çelik, Z., \& Boz, N. (2012). Turkey's youth profile. Ankara: SETA Publishing.

Kilcan, B. (2019). Using metaphors in educational sciences as data collection tools, sample application. In B. Kilcan (Ed.), Metaphor and An Application Guide for Metaphoric Studies in Education (2 ${ }^{\text {nd }}$ ed.) (pp. 89-108). Ankara: Pegem Academy.

Lakoff, G., \& Johnson, M. (2015). Metaphors: life, meaning and language (2 $2^{\text {nd }}$ ed.), (G. Y. Demir, Trans.). Istanbul: Ithaki Publications. (Original work published 1980).

Leino, A. L., \& Drankenberg, M. (1993). Metaphor: an educational perspective. University of Helsinki Department of Education Research Bulletin, 84, 1-70. https://doi.org/10.1080/00228958.2005.10532066

Levine, P. M. (2005). Metaphors and images of classrooms. Kappa Delta Pi Record, 41(4), 172-175. Online available from https://files.eric.ed.gov/fulltext/EJ724893.pdf

Miles, M. B., \& Huberman, A. M. (1994). Qualitative data analysis ( $2^{\text {nd }}$ ed.). CA: Thousand Oaks, Sage.

Morgan, G. (1997). Metaphor in management and organizational theories, (G. Bulut, Trans.). Istanbul: MESS.

Nasalski, I. (2004). Die politische metapher im Arabischen. untersuchungen zu semiotik und symbolik der politischen sprache am beispiel Ägyptens. Wiesbaden, Germany: Harrasowitz Verlag.

Parasız, G. (2018). Musical preferences of secondary school students and their expectations in music lessons (example of Erzurum province). In G. Mihladız (Ed.), Academic Researches in Educational Sciences (pp. 253-273). Ankara: Gece Academy.

Saban, A. (2009). Prospective teachers' mental images about the concept of student. The Journal of Turkish Educational Sciences, 7(2), 281-326. Online available from https://dergipark.org.tr/download/article-file/256272

Saban, A., Koçbeker, B. N., \& Saban, A. (2006). The evaluation of teacher candidates' perceptions about the concept of teacher through metaphor analysis. Educational Sciences Theory \& Practice, 6(2), 461-522.

Şahin, B. (2013). Teacher candidates' metaphoric perceptions related with mathematics teacher, mathematics and math lesson concepts. Mersin University Journal of The Faculty of Education, 9(1), 313-321. 10.17860/efd.03119

$\mathrm{Su}$, S.., Sağlam, A., \& Mutlu, Y. (2017). Comparing with metaphors related bilsem and school concepts of the perception levels of science and art center students. Journal of Giftedness Education and Creativity, 4(3), 91-108. Online available from http: //jgedc.org/? SID = hizmetlerimiz_detay \&anaid $=4 \&$ altid=9\&urid=47

Tavşanc1l, E., \& Aslan, A. E. (2001). Content analysis and application examples for verbal, written and other materials. Istanbul: Epsilon Press. 
Taylor, W. (1984). Metaphors of educational discourse. In W. Taylor (Ed.), Metaphors of Education, Studies in Education series 14 (pp. 4-20). London Heineman Educational Books.

Tez, İ. (2016). Investigating the secondary school students' perceptions in regard to concepts of music-music lesson and music teacher through the metaphors (Master's Thesis). Niğde: Niğde University. Online available from http://www.yok.gov.tr (Thesis No: 421595).

Tez, İ., \& Aydıner Uygun, M. (2016). A metaphorical analysis of middle-school students' perceptions on music lesson and music teacher. International Journal of Education and Human Sciences, 6(2), 415-453. Online available from http://kalemacademy.com/Cms_Data/Contents/KalemAcademyDB/Folders/SayiMakaleleri/ contents/DK82NBLT DFHJRAGF/2016-kalemueibd-11-kissayisi-makale-004-11.pdf

Uçan, A. (2005). Music education, the basic concepts, principles, approaches and the situation in Turkey. Ankara: Evrensel Music House.

Umuzdaş, S., \& Umuzdaş, M. S. (2013). An analysis of the student classroom teachers' perceptions about the music course through metaphors. International Journal of Human Sciences, 10(1), 719-729. Online available from https://www.j-humansciences.com/ojs/index.php/IJHS/article/view/2574

Uzunoğlu, Y. B. (2018). Determination of preservice preschool teachers' perceptions of music lesson through metaphors. Universal Journal of Educational Research, 6(6), 1305-1312. https://doi.org/10.13189/ujer.2018.060621

Wagenheim, G., Clark, R., \& Crispo, A. W. (2009). Metaphorical mirror: reflecting on our personal pursuits to discover and challenge our teaching practice assumptions. International Journal of Teaching and Learning in Higher Education, 20(3), 503-509. Online available from https://files.eric.ed.gov/fulltext/EJ869334.pdf

Yazic1, T. (2015). Metaphorcal perceptions of class teacher candidates in relation to music course concept. Academic Journals Educational Research and Reviews, 10(24), 2937-2943. https://doi.org/10.5897/ERR2015.2531

Yıldırım, A., \& Şimşek, H. (2008). Qualitative research methods in the social sciences (6 ${ }^{\text {th }}$ ed.). Ankara: Seçkin Press.

Yob, I. M. (2003). Thinking constructively with metaphors. Studies in Philosophy and Education, 22(2), 127-138. https://doi.org/10.1023/A:1022289113443

Zbikowski, L. M. (2008). Music and metaphor. In Raymond W. Gibbs, Jr. (Ed.), The Cambridge Handbook of Metaphor and Thought (pp. 502-524), New York: Cambridge University Press.

\section{Copyrights}

Copyright for this article is retained by the author(s), with first publication rights granted to the journal.

This is an open-access article distributed under the terms and conditions of the Creative Commons Attribution license which permits unrestricted use, distribution, and reproduction in any medium, provided the original work is properly cited. 